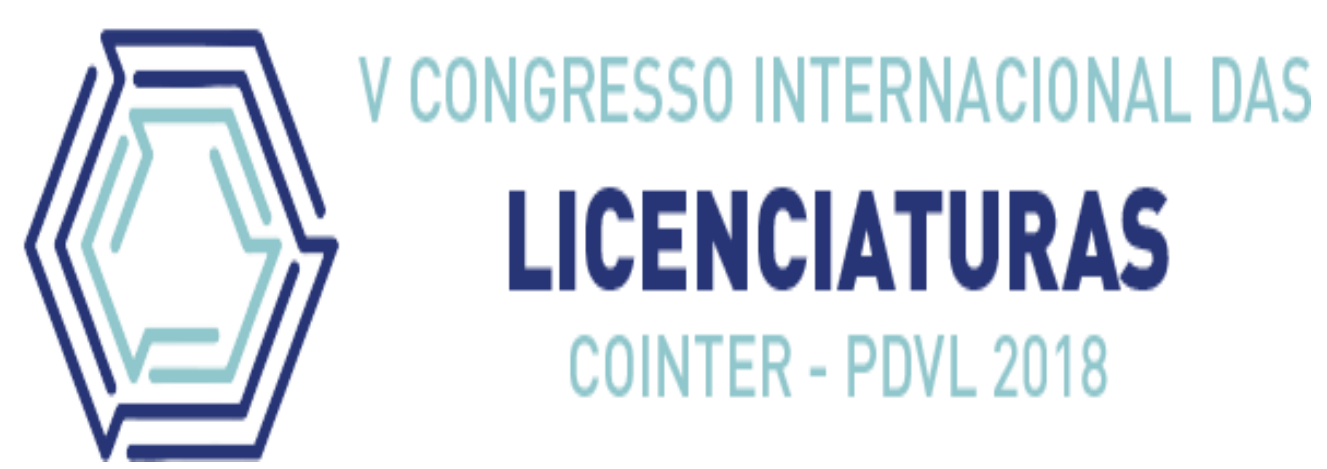

\title{
RELATO DE EXPERIÊNCIA SOBRE JOGO DIDÁTICO EM UMA AULA DE QUÍMICA
}

\begin{abstract}
Apresentação: Relato Experiência
Matheus Alves Barbosa ${ }^{1}$; Karolayne Andrade da Silva²; Claúdio Henrique Alves Perdigão ${ }^{3}$.

DOI: https://doi.org/10.31692/2358-9728.VCOINTERPDVL.2018.00314

\section{Introdução}

Segundo Chateau (1975: 13-14) define o jogo como um meio pelo qual o homem pode desenvolver plenamente as suas potencialidades. Através desse pensamento, percebemos a importância do jogo para o desenvolvimento humano.
\end{abstract}

No tocante à assimilação cognitiva, concordamos com Piaget, quando fala que:

"O jogo é uma pura assimilação que consiste em modificar a informação de entrada de acordo com as exigências do indivíduo" (Piaget,1970)

Os jogos didáticos têm esse poder de modificar a percepção dos estudantes para com aqueles conteúdos considerados mais difíceis, fazendo com que os estudantes se deparem com uma forma mais simples para aprender, entender e fixar os conteúdos dados em sala

A aplicação do jogo foi para melhor fixação do conteúdo dado em sala de aula, colocando em prática os conhecimentos adquiridos pelos estudantes e promovendo a possibilidade de uma maneira de participação dos estudantes na aula de química.

\section{Relato Experiência}

O jogo (batalha oxigenada) foi aplicado na Escola Estadual Cônego Fernando Passos, na cidade de Passira, Pernambuco.

\footnotetext{
${ }^{1}$ Licenciatura em Química, IFPE, matheusalves201629032000@gmail.com

${ }^{2}$ Licenciatura em Química, IFPE, karolandradepe@gmail.com

${ }^{3}$ Professor Mestre do Campus IFPE Vitória de Santo Antão, Pernambuco, claudio.perdigao@vitoria.ifpe.edu.br
} 
Os sujeitos envolvidos foram os estudantes das 04(quatro) turmas dando um total de 120 (cento e vinte) estudantes de $3^{\circ}$ ano do Ensino Médio da referida escola e contou com o auxílio e a participação da docente titular da disciplina de Química. A aplicação do jogo aconteceu no período de uma aula em cada turma.

Primeiro explicaram-se: as regras do jogo, os seus objetivos e os conteúdo envolvido, que neste caso é o conteúdo de funções oxigenadas. Em seguida, escolheram-se aleatoriamente os estudantes para virem até o jogo, e pediu-se para que escolhessem uma letra e um número. Caso o estudante pegasse uma carta do jogo que estivesse uma cadeia carbônica, teria que responder o nome daquele composto orgânico. Caso acertasse, escolheria quem seria o próximo jogador, caso errasse ou no local da carta estivesse uma bomba, o estudante teria que pagar uma prenda (que ficava a critério da turma).

Ao final do jogo os estudantes responderam uma atividade, que teve como objetivo gerar material para análises da eficácia dos jogos na esfera cognitiva.

\section{Resultado e discussão}

Com relação à participação dos sujeitos, observou-se um grande envolvimento dos mesmos na atividade proposta. Esse resultado contrapõe-se, de certa forma, ao resultado esperado antes da aplicação, dado que, em conversas informais com a docente da disciplina, houve relatos de dificuldades de envolvimento por parte dos estudantes. Pode-se admitir essa participação ao caráter lúdico dos jogos didáticos, que podem promover um maior interesse dos educandos.

\section{Consideração}

Com a aplicação do jogo foi possível observar a melhor interrasão dos estudantes em sala de aula, e obtendo um melhor intendimento do conteúdo dado. O uso do jogo foi uma metodologia alternativa onde foi possível apresentar o ensino da química de uma forma diferente e torna a aula mais interresante. Com a experiência vivenciada podemos ver a contribuição do jogo didático, que proporciona aos estudantes a opurtunidade de aprender com uma forma lúdica e mais chamativa.

\section{Referências}

https://repositorio-aberto.up.pt/bitstream/10216/71590/2/28409.pdf acessado em: 09/10/2018 https://docplayer.com.br/11302118-A-utilizacao-do-jogo-como-recurso-de-motivacao-e- 
aprendizagem.html

acessado em: 09/10/2018 